\title{
Investigations on Deposited Dust Fallout in Urban Doha: Characterization, Source Apportionment and Mitigation
}

\author{
Hanadi Al-Thani ${ }^{1}$, Muammer Koc ${ }^{1}$, Rima J. Isaifan ${ }^{2, *}$ \\ ${ }^{1}$ Division of Sustainable Development (DSD), College of Science and Engineering (CSE), \\ Hamad Bin Khalifa University (HBKU/ Qatar Foundation (QF), P.O. Box 5825, Doha, Qatar \\ ${ }^{2}$ Qatar Environment and Energy Research Institute (QEERI), Hamad Bin Khalifa University (HBKU)/ \\ Qatar Foundation (QF), P.O. Box 5825, Doha, Qatar
}

Copyright $\bigcirc 2018$ by authors, all rights reserved. Authors agree that this article remains permanently open access under the terms of the Creative Commons Attribution License 4.0 International License

\begin{abstract}
This preliminary study investigates and reports on the sources, characterization and possible mitigation of dust fallout in urban Doha, Qatar. Nine samples were collected from three different sites in close vicinity to the Solar Test Facility (STF) in west Doha during the winter of 2016 in Doha. The morphology and size distribution of the samples were analyzed using scanning electron and optical microscopy imaging techniques. It was found that the particulate matter had different shapes with an average particle size of $7.38 \mu \mathrm{m}$. The mass concentration of the elements, in order from greatest to smallest, was: $\mathrm{Ca}, \mathrm{Si}, \mathrm{Fe}, \mathrm{Mg}, \mathrm{Al}, \mathrm{Ti}, \mathrm{K}, \mathrm{Na}, \mathrm{S}$, and $\mathrm{Cl}$. The enrichment factor showed extremely high ratios of $\mathrm{Cl}$ and $\mathrm{S}$, while $\mathrm{Ca}$ had significant enrichment value. The sources of PM samples were identified to be mainly of natural origin (around 60\%) with the balance attributed to anthropogenic sources. The natural sources were related to soil/crustal matter, marine salt and desert dust while the anthropogenic sources were mainly due to transportation and construction activities, which have been experiencing dramatic increase during the past decade in Doha along with its rapid economic development. To this end, several possible mitigation strategies to abate urban PM and its harmful effects were also proposed considering the local living and cultural conditions in Qatar.
\end{abstract}

Keywords Particulate Matter, Environmental Management, Elemental Composition, Enrichment Factor, Source Apportionment, Mitigation Strategies, Qatar

\section{Introduction}

Particulate matter (PM) is one of the atmospheric aerosols that are mainly generated from mineral dust produced from windblown soils and deserts. PM largely contributes to the global aerosol loading and has strong impacts on regional and global climates as well as on the health of living creatures and structure [1]. Atmospheric PM generally contains a variety of solid and liquid particles of different sizes that originate from many sources, which affect the chemical and physical properties of PM. PM are classified as primary and secondary aerosols according to their formation mechanism; where primary particles are directly emitted to the atmosphere and the secondary particles are formed via chemical reaction between their gaseous precursors [2][3]. Moreover, ambient PM can be generally classified based on their size into coarse, fine and ultrafine particulates. Coarse particles have mass median aerodynamic diameter (MMAD) of 2.5-10 $\mu$ m, whereas fine particulates have MMAD $\leq 2.5 \mu \mathrm{m}$ and ultrafine particulates have MMAD $\leq 0.1 \mu \mathrm{m}[4]$.

It is of critical importance that the particulate matter is well characterized and analyzed in terms of its sources, physical properties, chemical composition and size distribution to develop effective mitigation and/or prevention strategies to reduce their adverse effects on health of humans, living creatures and structures. Information on elemental and chemical composition of aerosol size fractions provides insight into PM chemistry and its impact on the environment and human health [5]. The smaller the particle size (fine and ultrafine PM), the greater their potential to affect human health since the smaller particle in size can penetrate deeper into lungs and other organs causing extensive damage and chronic health problems [2]. Therefore, proper identification of PM sources is crucial for informing policy makers to take suitable legislation to better manage PM air pollution within an airshed [6].

PM chemical composition varies from one place to another due to different sources, climate conditions and seasons. The chemical composition of PM has been investigated in different areas around the world [2][7][8][9][10][11]. This task is of critical importance to investigate and understand PM sources, hence, to propose 
applicable tailored mitigation strategies. In general, natural pollutants are considered as the main source for large or coarse particles while anthropogenic emissions are usually responsible for fine and ultrafine particle emissions [12][13]. Examples of natural sources of particulate matter are volcanoes, sea spray, grassland fires, desert dust and a variety of biological sources (pollen, bacteria, fungal spores, fragments of vegetable organisms and of animals) [2]. On the other hand, increasing amount and type of anthropogenic particles have been identified due to an ever expansion of human activities such as the burning of fossil fuels in vehicles, domestic heating, power plants, construction activities and industrial processes [2].

Although dust storms are common phenomenon in arid and semi-arid regions worldwide, they are natural events that occur frequently in the Arabian Peninsula [14], which generate high level of airborne PM concentration. Dust storms carry PM of natural and anthropogenic components that might have considerable impact on human society in any residential area. Hence, improving our understanding on the characteristics of dust fallout properties, characteristics and sources would help decision makers and researchers to develop technical solutions and propose policies appropriate for implementation in this region.

Recently, several works have reported on the characterization of airborne particulate matter in this area $[11][15][16]$, but there is considerable lack on the identification of the sources of these particles [12][14]. Aissa et al. [16] had characterized dust samples collected in Doha-Qatar during the summer. It was found that calcite dominates the dust composition with $58 \%$ atomic content. Moreover, Javed el al. [15] studied dust accumulated naturally on photovoltaic (PV) panels in Doha over a period of ten months to understand its soiling effect on PV power output. Calcium was found to be the most abundant element, followed by silicon, iron, magnesium and aluminum. Moreover, X-ray diffraction analyses helped identifying calcite, dolomite and quartz to be the dominant minerals in the accumulated dust, with gypsum to be a minor component. Al-Awadhi et al. [17] studied the deposition and characteristics of dust fallout in Kuwait city. They found that Kuwait city is characterized with high dust deposition rate of $0.6 \mathrm{~kg} / \mathrm{m}^{2} /$ year ranking the first out of 56 dust deposition rates observed worldwide. The dominant minerals were found to be quartz and calcite with traffic identified as a major anthropogenic source. Al-Dousari et al. [18] studied dust fallout in several preserved and open areas in Kuwait and found out that dust in this region is characterized by higher carbonates and lower clay minerals compared to the dust in Sahara Desert, east and middle Asian regions. The content of dust fallout samples were dominated by an average of $44 \%$ quartz and followed by high amount of calcite.

Nevertheless, very few works had been done to identify sources of dust in the Arabian Peninsula. Al-Dousari et al. [18] identified five major sources of dust in Kuwait using meteorological data and satellite images. The sources were: the western desert of Iraq, the Mesopotamian Flood Plain, northeastern desert of Saudi Arabia and drained marshes in southern Iraq and Iran. A recent work had reported on the PM composition and sources in the United Arab Emirates (UAE), which has almost the same geographical nature and weather conditions as of the State of Qatar [12]. In their study, the natural sources of PM in UAE were found to be sea salts, crustal materials, soil and ash. On the other hand, the main anthropogenic sources of PM were linked with industrial and transportation emissions [12]. Khodeir et al. [11] reported recently on the sources and elemental composition of $\mathrm{PM}_{2.5}$ and $\mathrm{PM}_{10}$ in Jeddah city in Kingdom of Saudi Arabia. They found that in both $\mathrm{PM}_{2.5}$ and $\mathrm{PM}_{10}$, sources were mainly due to heavy oil combustion (characterized by high nickel and vanadium), resuspended soil (characterized by high calcium, iron, aluminum and silicon) and a mixed industrial source. Moreover, two specific sources were found to be associated with $\mathrm{PM}_{2.5}$. These were traffic (characterized by lead, bromine and aluminum) and another industrial source mixture.

Transportation emissions in urban cities are considered as a major contributor of anthropogenic PM and need to be further investigated and characterized to develop tailored mitigation strategies to minimize their adverse effects on the habitants and habitat of urban regions. Transportation involves combustion of fossil fuels in different means, ways and locations to produce energy that is converted into motion of vehicles [19]. During this combustion process, air pollution is created from incomplete burning and oxidation of carbon, hydrocarbon and other elements present in the fuel and combustion air producing various gaseous pollutants in addition to soot and particulate matter.

Road transport has become the dominant mode of travel in urban and rural areas [20]. Nevertheless, the type and share of fossil fuel used in the transport sector varies from one region to another [19] depending on the available energy sources, regulations, demographics and living standards. A recent study of six cities in developing countries found that the share of fossil fuels combustion ranged between $4-35 \%$ in the transport sector [19]. In India alone, it was estimated that $72 \%$ of air pollution is caused by vehicular traffic [20].

Moreover, in addition to traffic emissions of particulate matter in urban areas, construction activities have contributed to anthropogenic or fugitive PM emissions in areas with increasing urbanization and infrastructure development rates. In the Arabian Peninsula, construction activities have contributed significantly to elevate dust concentration that is mainly characterized by high calcite and carbonaceous matter content. Hence, it is of paramount importance to consider mitigation of construction PM emissions in urban areas as natural sources of airborne particulate matter are usually hard to control.

In this work, several samples of deposited bulk dust were 
collected to have a preliminary understanding of the composition as well as possible sources of PM in urban Doha. Moreover, the particle size distribution and enrichment factor (EF) were calculated, and the sources of PM composition were identified. The objectives of this work are to (1) investigate the physical and chemical properties of bulk dust samples collected in different locations around Doha, which may be representative of residential, traffic and commercial backgrounds, (2) identify the possible sources of these samples whether it is natural or anthropogenic, and (3) recommend possible technical and policy driven mitigation strategies to reduce PM emissions from the two main anthropogenic sources (traffic and construction). In continuation to this preliminary study, more in-depth work and reporting has been in progress by the Air Quality and Climate Change Research Group at QEERI/HBKU with a full year systematic collection of 50 dust fallout and atmospheric aerosols collected on Teflon filters on monthly basis from urban Doha and other major cities to characterize PM and identify their sources in several locations around the state of Qatar to be the first study of its kind for the country.

\section{Methodology}

Nine bulk dust samples were collected around urban Doha in winter between December 2016 and February 2017 (locations are identified in the map in Fig. 1). Sampling is performed as dust is deposited on clean glass surfaces and collected on monthly basis as reported in other studies on fallout dust collection [14][18]. One sample was obtained from each location (Fig. 1) for each of the three months mentioned in the study) providing a total of nine samples. The bulk samples collected were considered mainly coarse to have an overlook of dominant elements and sources in the urban area of Doha. The size distribution of the samples was characterized via optical microscope where optical images were taken and the particle size of about 300 particles was measured in each image [21][22][16][23]. The chemical composition of the PM samples was performed via SEM/EDS model JCM-6000PLUS NeoScope Bench top. In theory, this electron microscope provide an image when a focused beam of electrons bombards the surface of a sample, therefore an x-ray is produced from the sample [24]. This instrument employs two different types of detectors which are secondary and backscattered electrons detectors. In this study, Secondary Electron mode used to acquire an image of the cross sections under study with a high magnification and resolution. This type of detectors was selected because the cross section illuminates shorter wavelength associated with the electrons to attain high magnification. According to Goldstein et al. [25], the resolution is determined as a function of the density which depends on the penetration of the electron beam to a certain depth in a sample. The mass concentrations of 10 elements ( $\mathrm{Al}, \mathrm{Ca}, \mathrm{Na}, \mathrm{Mg}, \mathrm{Cl}, \mathrm{Fe}, \mathrm{K}, \mathrm{S}$, $\mathrm{Si}, \mathrm{Ti})$ were determined for each sample.

The acidity of the dust samples was measured following the standard method where $50 \mathrm{~g}$ of dust was added into 100 $\mathrm{ml}$ of de-ionized water. The mixture was stirred at high speed at room temperature for 3 hours. $\mathrm{pH}$ measurements were taken every 5-10 minutes until $\mathrm{pH}$ value was constant. The values were taken daily for 5 days and the final value was reported.

The enrichment factor (EF) relates the concentration of an element in PM to its average concentration naturally in earth's continental crust. It is widely used as an approach to characterize the chemical composition of airborne PM. The EF index of potential contamination is calculated by the normalization of one metal concentration in the PM sample with respect to the concentration of a reference element [26]. A reference element is an element particularly stable in which it is characterized by the absence of vertical mobility and/or degradation phenomena and its concentration should not be anthropogenically altered [27]. Aluminum was used as the reference element as it is a conservative element and a major constituent of clay minerals, and it has been used in many other studies successfully by several scientists as given in eqn. (1) [10][28]:

$$
\mathrm{EF}=(\mathrm{X} / \mathrm{Al})_{(\text {aerosol) }} /(\mathrm{X} / \mathrm{Al})_{(\text {crust) }}
$$
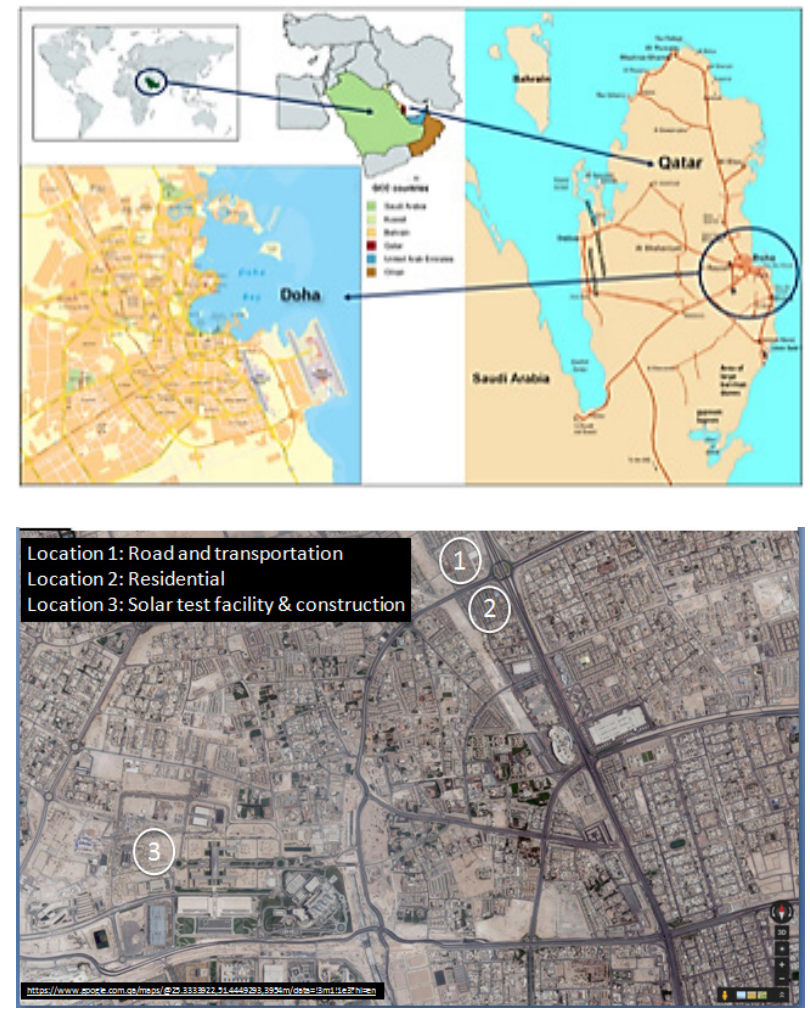

Figure 1. Map showing (top) Doha city and (bottom) the locations from which nine samples were collected for analysis in this work.

Hence, an EF of around unity indicates that the dominant source is natural crustal PM, and an EF value $>10$ indicates 
an anthropogenic input to the PM. Aluminum (Al) was used as the normalizing crustal element in calculating the EFs, assuming that its anthropogenic input was minor and negligible. Generally, an element is assumed to be of natural origin when its enrichment factor is less than 10 [29][27][30].

\section{Results and Discussions}

\subsection{Dust Fallout Deposition Rate}

The average monthly dust fallout deposition rate in our study was about $3.7 \mathrm{Ton} / \mathrm{km}^{2}$. Although our value presents the average deposition during winter season as per the duration of the sampling time presented in the methodology section, this value is considered moderate in comparison with other regional and other cities around the world (Table 1).

Table 1. Average monthly amounts of dust fallout $\left(\mathrm{Ton} / \mathrm{km}^{2}\right)$ in regional and global cities

\begin{tabular}{ccccc}
\hline Location & Country & $\begin{array}{c}\text { Monthly } \\
\text { dust } \\
\text { fallout }\end{array}$ & $\begin{array}{c}\text { Study } \\
\text { period }\end{array}$ & References \\
\hline $\begin{array}{c}\text { Riyadh } \\
\text { city }\end{array}$ & $\begin{array}{c}\text { Saudi } \\
\text { Arabia }\end{array}$ & 37.8 & 2012 & {$[14]$} \\
\hline Open area & Kuwait & 5.1 & $2011-2012$ & {$[17]$} \\
\hline $\begin{array}{c}\text { Preserved } \\
\text { area }\end{array}$ & Kuwait & 1.4 & $2011-2012$ & {$[17]$} \\
\hline Baghdad & Iraq & 18.3 & $2008-2009$ & {$[31]$} \\
\hline Libya & Libya & 12.9 & $2000-2001$ & {$[32]$} \\
\hline Nevada & USA & $0.3-1.3$ & $1984-1999$ & {$[33]$} \\
\hline California & USA & $0.5-2.8$ & $1984-1999$ & {$[33]$} \\
\hline Doha & Qatar & 4.2 & 2015 & {$[15]$} \\
\hline Doha* & Qatar & 3.7 & 2016 & $\begin{array}{c}\text { Present } \\
\text { work }\end{array}$ \\
\hline
\end{tabular}

* measured for winter 2016

\subsection{Morphology and Particle Size Distribution}

Figure 2 shows representative SEM micrographs of dust particles taken at different magnifications. The micrographs show different size and morphologies of dust particles with some agglomeration in some samples. Figure 3 shows the size distribution of the particles, which ranges from 1-100 $\mu \mathrm{m}$ based on the frequency number of all particles counted in categories as shown. The average particle size of the samples in this study collected in winter is found to be $7.38 \mu \mathrm{m}$. It is worth mentioning that the average particle size of particulate matter in our previous study of the samples collected in the summer was found to be around $2.4 \mu \mathrm{m}$ [16]. The seasonal variation in PM size was reported to be larger in winter compared to summer for other locations such as China [34], Australia [35] where agglomeration of particles in the winter was noticed due to wet weather.
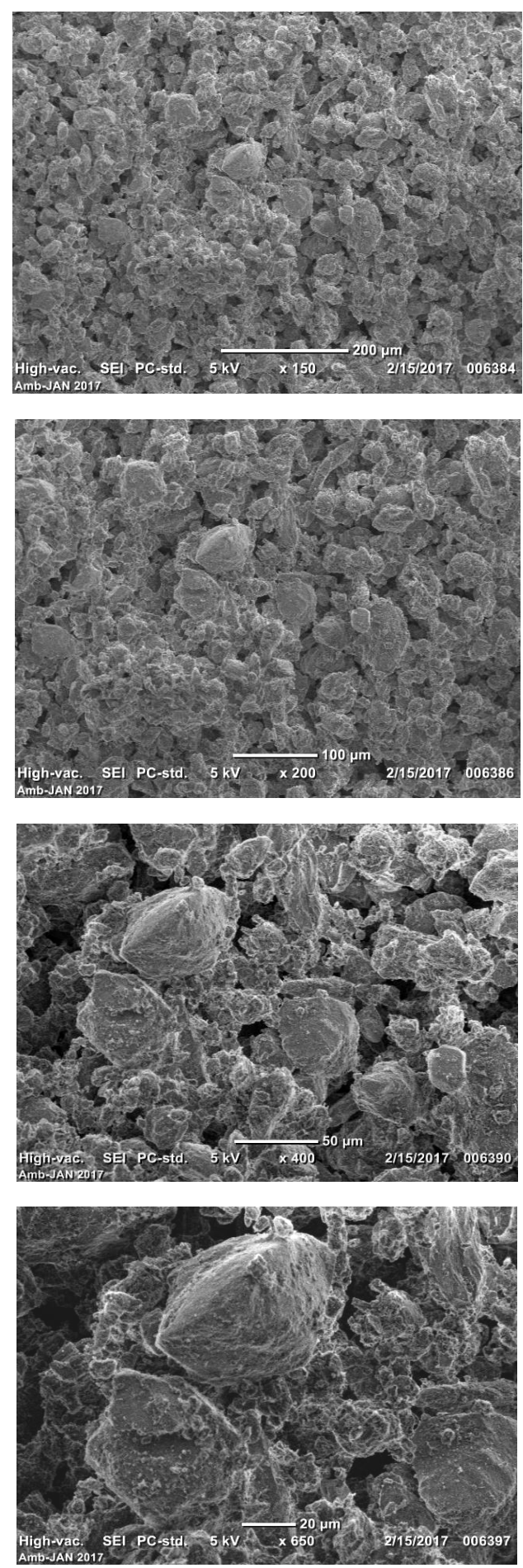

Figure 2. Representative SEM micrographs with various magnifications of the dust particles

Furthermore, two principle quantities were identified to analyze the particle size and shape of the particulate matter; the aspect ratio $(C t)$ and the shape factor $\left(A_{\text {shape }}\right)$. The aspect ratio is given by eqn. (2) [36][16]:

$$
C_{t}=\pi\left(L_{p r o j}\right)^{2} / 4 \mathrm{~A}
$$

where $A$ is the cross-sectional area, and $L_{p r o j}$ is the longest projection length of the dust particle. 
A shape factor of unity corresponds to a perfect circle which applies well to the small particles in our study as they can be assumed to be spherical in shape while for the larger particles; the median aspect ratio is estimated to be around 2.54 .

On the other hand, the shape factor of particles can be estimated via eqn. (3) [36][16]:

$$
A_{\text {shape }}=P^{2} / 4 \pi A
$$

where $\mathrm{P}$ is the perimeter of the dust particle. For spherical particles, shape factor approaches unity while for longitudinal dust particles, the average shape factor has been estimated to be around 1.77 .

The shape factor is of paramount importance for particle-surface adhesion studies. When the shape factor approaches unity for a spherical particle that would indicate that the contact area between the particle and the surface is almost a point, while as the shape factor increases, the irregular shape would have larger contact area which might affect the adhesion force between the particle and the surface. A full analysis original study has been conducted by our group to evaluate four adhesion forces that take place under humid hot weather condition where the contact area depending on the particle shape plays a critical role to estimate van der Waal and capillary adhesion forces as reported by earlier studies [37][38].

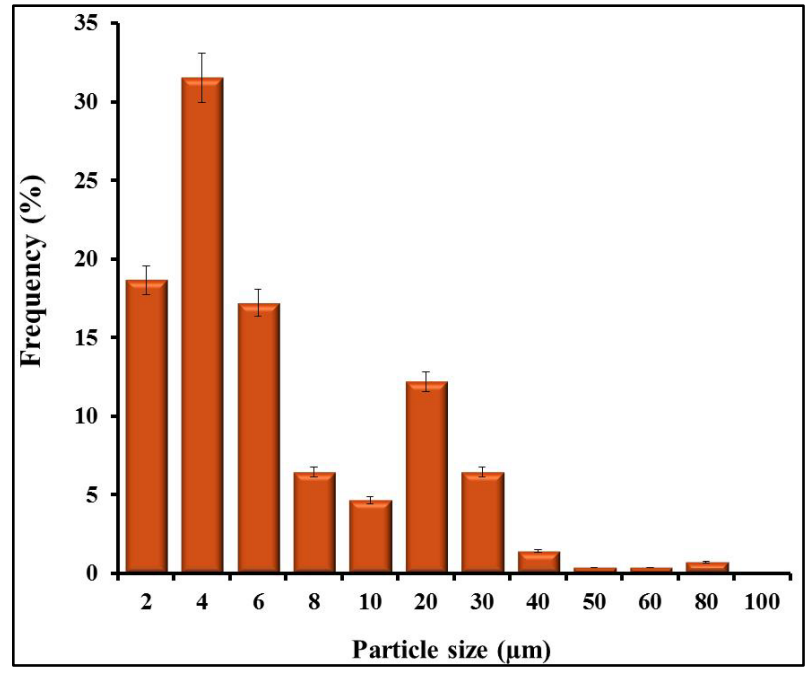

Figure 3. Particle size distribution histogram of the samples collected in winter.

\subsection{Alkalinity}

The alkalinity of particulate matter and dust particles is of critical importance to understand their effect on materials. One particular example is that dust with high alkalinity impacts glass surfaces through the mud formation of dust particles accumulation on solar panels [39]. The $\mathrm{pH}$ of our dust samples ranged between 7.51-7.88. Very few studies measured dust alkalinity with the aim to further investigate the influence on PV glass surfaces. In a recent study in Saudi Arabia, Hassan et al. [40] measured the $\mathrm{pH}$ of mud solution (liquid) that was extracted from the mixture of dust particles and water. The $\mathrm{pH}$ of the mud liquid was found to be in the range of 7.5-8.4 indicating that the solution is basic due to the presence of alkaline and alkaline earth metals dissolved in water. In a continuation of this work, the same group of researchers reported in another study [36] that due to the presence of $\mathrm{OH}^{-}$ions in the mud solution $(\mathrm{pH}=8.4)$, small cavities were formed in the glass surface because of surface etching. In this case, $\mathrm{KOH}$ ions in the mud solution were responsible for the local etching of the glass surface, which in turn, increased the surface texture of the glass after the mud removal as reported by Yilbas et al. [36].

\subsection{Mass Concentrations of Chemical Elements}

Figure 4 presents the average elemental composition of the samples collected in Doha during winter with their corresponding metal oxides reported in Table 2 . The mass concentration of elements in order from greatest to smallest was $\mathrm{Ca}, \mathrm{Si}, \mathrm{Fe}, \mathrm{Mg}, \mathrm{Al}, \mathrm{Ti}, \mathrm{K}, \mathrm{Na}, \mathrm{S}$ and $\mathrm{Cl}$. This elemental composition is found to be similar to the composition reported earlier by Yilbas et al. [36] for the dust particles collected after the sand storm in Saudi Arabia in 2014 and in agreement with the study by Javed et al. [15] on the characterization of PM naturally deposited on PV panels in Doha. The domination of calcium and silica is a natural characteristic of the dust in the Arabian Peninsula [15][18]. On the other hand, some variations of the composition were found when compared with the dust samples collected in summer in our previous study [16]. The main variation is, for instance, the presence of 4.03 and $1.48 \%$ mass concentration of sodium and chlorine, respectively which were not traced in the summer samples. This is in agreement with the study conducted in Saudi Arabia where the authors found that the concentration of chlorine varied from one particle to another in the dust samples collected in the Arabian Gulf. It was also clarified that when the EDS (Energy Dispersive X-ray Spectroscopy) data do not satisfy the molar ratio for $\mathrm{NaCl}$, that indicates that $\mathrm{NaCl}$ is dissolved in the compound form rather than being present as salt crystals [36].

The sulfur concentration is correlated with calcium in most studies [36][41], which is associated with the formation of anhydrite or gypsum component $\left(\mathrm{CaSO}_{4}\right)$. Nevertheless, scanning electron microscopy (SEM) studies of atmospheric aerosols have revealed that direct emissions of sulfur from coal, oil and fuel combustion is the substantial source of primary atmospheric sulfate in the form of $\mathrm{CaSO}_{4}$ [42]. Moreover, several studies had confirmed that traffic exhausts and shipping activities were the main contributors to secondary sulfates in particulate matter [42][43][44].

The ratio of $\mathrm{Ca}$ to $\mathrm{Si}$ in our study was found to be 1.96 compared with 1.53 for the summer samples, which 
indicates high construction activities that are more frequent and intense in the winter due to the domination of good weather conditions for working hours during the day. Moreover, other studies have reported different $\mathrm{Ca}$ to $\mathrm{Si}$ ratio which was around 0.18 for African dust [45] and 0.76 for dust particles collected in Kingdom of Saudi Arabia [36]. It is as well indicated in several studies in Kuwait that wind speed plays an important role in the increase of silicate fraction over carbonate in the summer season [17][18]. This is in agreement with the findings of our current study as indicated above where higher $\mathrm{Ca}$ is observed in winter compared with its concentration in the previous study conducted in summer [16].

It can be seen from Table 2 that titanium oxide had the highest ratio of abundance relative to the Earth's upper continental crust composition. Titanium oxide has been associated with crustal dust and road dust resuspension [46]. The following high ratios after titanium oxide were related to calcium oxide (originating from calcite), magnesium oxide (from dolomite) and iron oxide (present in hematite and wuestite) [16][46][47].

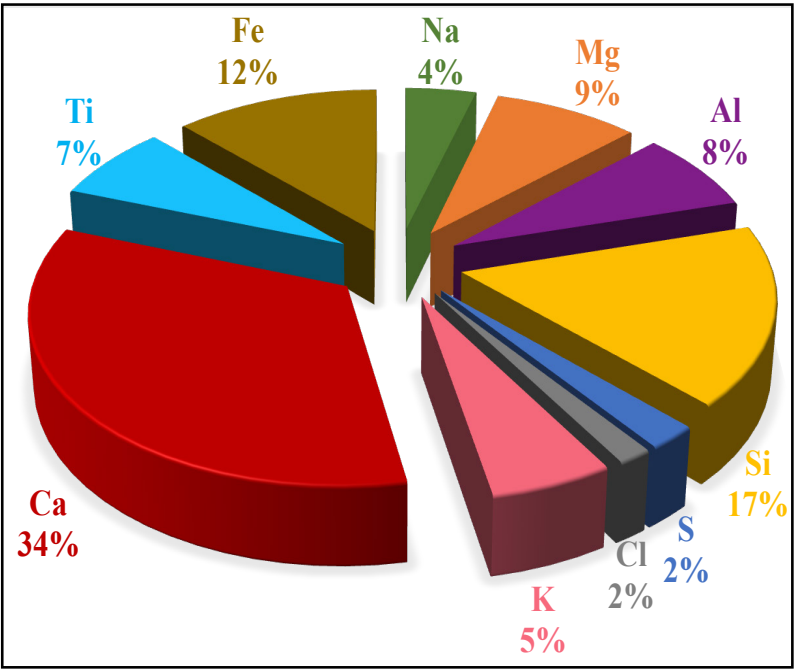

Figure 4. Mass percentage of the elemental composition of PM particles.

Table 2. Average PM composition of metal oxides (mass \%) in the collected dust samples.

\begin{tabular}{|c|c|c|c|c|c|}
\hline \multirow[b]{2}{*}{$\begin{array}{c}\text { Metal } \\
\text { Oxide }\end{array}$} & \multicolumn{5}{|c|}{ Mass \% upper continental crust } \\
\hline & $\begin{array}{c}\text { Mass \% (our } \\
\text { samples) }\end{array}$ & $\begin{array}{c}\text { Taylor \& } \\
\text { McLennan (1985) } \\
\end{array}$ & Wedepohl (1995) & $\begin{array}{l}\text { Average } \\
\text { reported }\end{array}$ & Ratio of Abundance \\
\hline $\begin{array}{c}\text { Sodium } \\
\text { oxide }\end{array}$ & 2.55 & 3.89 & 3.56 & 3.72 & 0.68 \\
\hline $\begin{array}{l}\text { Magnesium } \\
\text { oxide }\end{array}$ & 9.46 & 2.20 & 2.30 & 2.25 & 4.21 \\
\hline $\begin{array}{c}\text { Aluminum } \\
\text { oxide }\end{array}$ & 6.76 & 15.17 & 15.05 & 15.11 & 0.45 \\
\hline $\begin{array}{c}\text { Silicon } \\
\text { oxide }\end{array}$ & 25.25 & 65.89 & 66.8 & 66.34 & 0.38 \\
\hline $\begin{array}{r}\text { Sulfur } \\
\text { oxide }\end{array}$ & 3.39 & NA & NA & NA & NA \\
\hline $\begin{array}{c}\text { Potassium } \\
\text { oxide }\end{array}$ & 1.38 & 3.39 & 3.19 & 3.29 & 0.42 \\
\hline $\begin{array}{c}\text { Calcium } \\
\text { oxide }\end{array}$ & 33.30 & 4.19 & 4.24 & 4.21 & 7.90 \\
\hline $\begin{array}{c}\text { Titanium } \\
\text { oxide }\end{array}$ & 6.72 & 0.50 & 0.54 & 0.52 & 12.92 \\
\hline $\begin{array}{l}\text { Iron } \\
\text { oxide }\end{array}$ & 10.18 & 4.49 & 4.09 & 4.29 & 2.37 \\
\hline
\end{tabular}

*Average reported: the average value of the mass \% of the metal oxide composition as reported by Taylor \& McLennan and Wedepohl.

${ }^{\#}$ Ratio of abundance $=$ mass $\%$ in our samples $/$ average mass $\%$ reported

\subsection{Enrichment Factor of Chemical Elements}

Figure 5 shows the enrichment factor results. It has been reported that five contamination categories are recognized on the basis of the enrichment factor:

$\mathrm{EF}<2$ : depletion to mineral enrichment;

$2 \leq \mathrm{EF}<5$ : moderate enrichment;

$5 \leq \mathrm{EF}<20$, significant enrichment;

$20 \leq \mathrm{EF}<40$ : very high enrichment; and

$\mathrm{EF}>40$ : extremely high enrichment [27][48].

These categories have been applied to our samples and the results are summarized in Table 3 . 


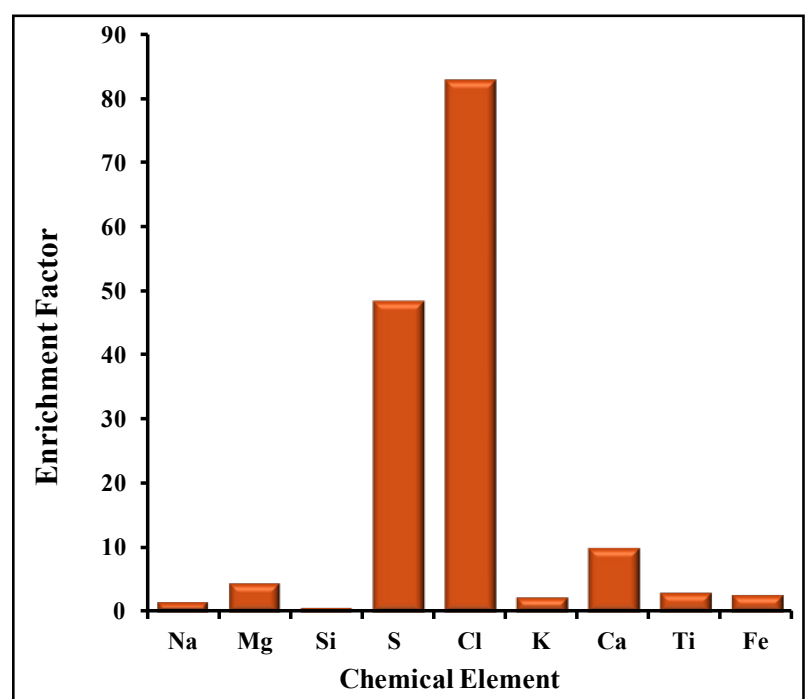

Figure 5. Enrichment factors of elements referred to crust dust in total size particle samples.

Table 3. Contamination level of the elements found in the dust samples as per EF values.

\begin{tabular}{cc}
\hline Element & Level of Contamination \\
\hline $\mathrm{Na}$ & Depletion to mineral enrichment \\
\hline $\mathrm{Mg}$ & Moderate enrichment \\
\hline $\mathrm{Si}$ & Depletion to mineral enrichment \\
\hline $\mathrm{S}$ & Extremely high enrichment \\
\hline $\mathrm{Cl}$ & Moderate enrichment \\
\hline $\mathrm{K}$ & Significant enrichment \\
\hline $\mathrm{Ca}$ & Moderate enrichment \\
\hline $\mathrm{Ti}$ & \\
\hline $\mathrm{Fe}$ &
\end{tabular}

The results of EF show that there is an extreme high enrichment of two elements $(\mathrm{S}$ and $\mathrm{Cl}$ ) while $\mathrm{Ca}$ has been found to have significant enrichment. The high enrichment factor of sulfur indicates that there is a major contribution by an anthropogenic source, which increases sulfur concentration relative to its concentration in continental earth crust. In addition, the high enrichment factor for chlorine is expected in this region due to its proximity to the Gulf and the domination of north west wind that carries water salt particulates into the inner lands [18][36]. Similar results on high enrichment factors of $\mathrm{S}$ and $\mathrm{Cl}$ in coarse particulates were reported recently by Khodeir et el. [11] with $\mathrm{EF}$ of 490 and 430 for both elements, respectively. On the other hand, the significant enrichment of $\mathrm{Ca}$ is in agreement with the domination of carbonate matter as reported earlier for studies in Qatar and other Arabian Peninsula countries [15][17][18][49].

\section{Source Apportionment of PM Composition}

In urban areas, several sources can be specified for the composition of PM in aerosols. Previous studies reported that coarse fractions of PM can be produced naturally by the mechanical break up of larger solids. These solids may originate from agricultural processes and soil [50], traffic and unpaved roads [51] or mining operations [52]. Moreover, traffic and vehicular emissions produce major portions of PM which can be also re-suspended from road surface or due to tyre and break wear [24]. On the other hand, the small fraction of PM which are less than $0.1 \mu \mathrm{m}$ in size can be produced basically from the condensation of combustion products when fossil fuel burning takes place in high temperatures [24][53]. Our analysis of the elemental composition shows that there are mainly five sources of the PM samples collected in urban Doha: Construction $(\mathrm{Ca}, \mathrm{K})$, transportation (S), soil/agriculture $(\mathrm{Fe}, \mathrm{Ti})$, desert dust $(\mathrm{Si}, \mathrm{Al})$ and sea salt $(\mathrm{Mg}, \mathrm{Na}, \mathrm{Cl})$ as per (Table 4 and Fig. 6). These findings are in accordance with previous source apportionment works reported by other groups based on the elemental signature and their combinations from respective sources [11][54][55][56][6].

Table 4. Possible sources of elements present on PM collected in Doha.

\begin{tabular}{|c|c|c|c|}
\hline Element & Possible sources & Source type & References \\
\hline $\mathrm{Na}$ & Earth crust & Natural & {$[57][58]$} \\
\hline $\mathrm{Mg}$ & $\begin{array}{l}\text { Soil related, } \\
\text { Oceans }\end{array}$ & Natural & $\begin{array}{l}{[59]} \\
{[60]}\end{array}$ \\
\hline $\mathrm{Al}$ & $\begin{array}{c}\text { Soil related, crustal } \\
\text { sources } \\
\text { Brake Wear }\end{array}$ & $\begin{array}{c}\text { Natural } \\
\text { Anthropogenic }\end{array}$ & $\begin{array}{l}{[59]} \\
{[61]}\end{array}$ \\
\hline $\mathrm{Si}$ & $\begin{array}{c}\text { Soil related, } \\
\text { Tyre Wear }\end{array}$ & $\begin{array}{c}\text { Natural } \\
\text { Anthropogenic }\end{array}$ & $\begin{array}{l}{[59]} \\
{[61]}\end{array}$ \\
\hline $\mathrm{S}$ & $\begin{array}{l}\text { Brake Wear, } \\
\text { Tyre Wear, } \\
\text { Diesel exhaust }\end{array}$ & Anthropogenic & {$[61]$} \\
\hline $\mathrm{Cl}$ & $\begin{array}{c}\text { Sea salt }(\mathrm{Cl}) \\
(\mathrm{ClO}) \text { can be due to } \\
\text { the reaction of } \\
\text { chlorine with ozone* }\end{array}$ & Natural & $\begin{array}{c}{[62]} \\
{[63][64]}\end{array}$ \\
\hline K & $\begin{array}{c}\text { Combustion process } \\
\text { (Transportation) } \\
\text { Oceans }\end{array}$ & $\begin{array}{c}\text { Anthropogenic } \\
\text { Natural }\end{array}$ & $\begin{array}{l}{[59]} \\
{[60]}\end{array}$ \\
\hline $\mathrm{Ca}$ & $\begin{array}{l}\text { Soil related, } \\
\text { Fly ash from concrete } \\
\text { in construction }\end{array}$ & $\begin{array}{c}\text { Natural } \\
\text { Anthropogenic }\end{array}$ & $\begin{array}{c}{[59][65]} \\
{[66]}\end{array}$ \\
\hline $\mathrm{Ti}$ & $\begin{array}{c}\text { Soil dust, } \\
\text { Crustal sources }\end{array}$ & Natural & [59] \\
\hline $\mathrm{Fe}$ & $\begin{array}{c}\text { Soil dusts, } \\
\text { Break wear, Building } \\
\text { construction }\end{array}$ & $\begin{array}{c}\text { Natural } \\
\text { Anthropogenic }\end{array}$ & $\begin{array}{l}{[67]} \\
{[68]}\end{array}$ \\
\hline
\end{tabular}

* The formation of $\mathrm{ClO}$ takes place when chlorine breaks ozone's bonds and pulls off one atom of oxygen, forming a chlorine monoxide molecule and oxygen as per the following equation: $\mathrm{O}_{3}+\mathrm{Cl} \rightarrow \mathrm{ClO}+\mathrm{O}_{2}$ 


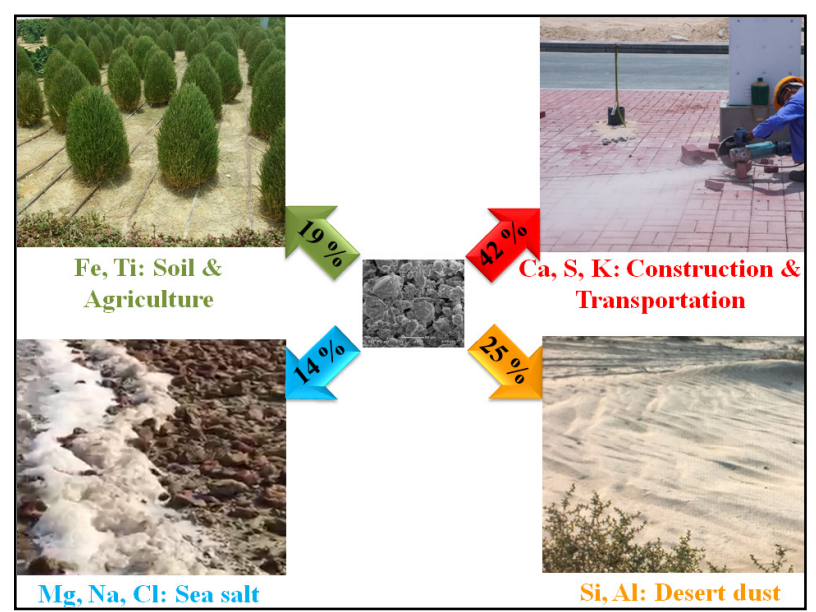

Figure 6. Source contribution of different elements as per the composition of PM samples collected in urban Doha.

On the other hand, the two most abundant elements in the samples $(\mathrm{Ca}, \mathrm{Si})$ in addition to Fe were plotted for each group of samples collected from residential, construction and transportation as shown in Fig. 7. It can be seen that the highest concentration of $\mathrm{Ca}$ is within the construction sites while residential houses surrounded by soil and plants/gardens are richer with iron. The roads reflecting transportation has much less concentration of these elements which are considered of natural source as traffic emissions are most characterized with sulfur and heavy metals such as $\mathrm{Zn}, \mathrm{Pb}$ and $\mathrm{Cu}$ [11][69].

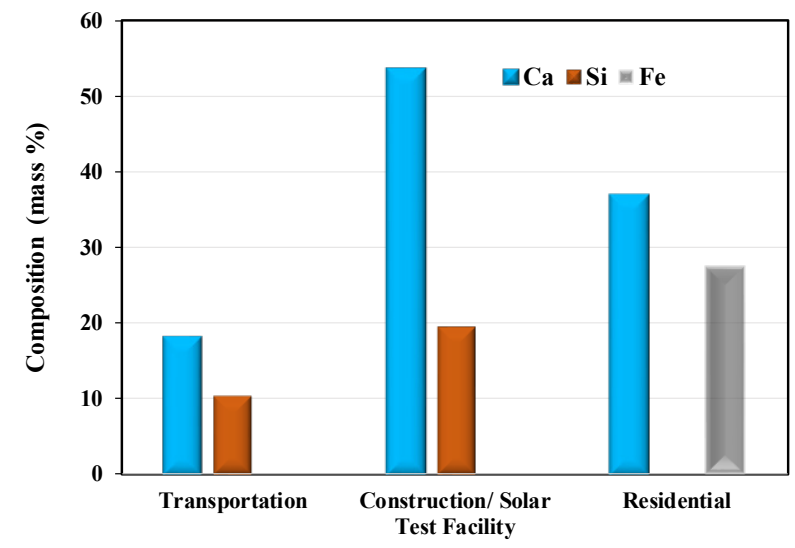

Figure 7. The concentration of the most abundant elements of samples from each site.

\section{Mitigation Strategies}

Particulate matter pollution can be minimized by pollution prevention and emission control measures. Prevention of pollution is usually more cost-effective than controlling and even more cost-effective than cleaning it [70]. General recommendations to prevent the emission of PM at the first stage can be achieved by avoiding burning fuels, walking instead of using vehicles, using renewable energy instead of depending on fossil fuels, etc.
Nevertheless, controlling fugitive emissions in urban cities can be challenging and requires the engagement of public, constructors, local municipality decision makers, controllers, farmers and users of exposed ground and unpaved roads. In an attempt to achieve high level of fugitive dust control in urban sites, California Resources Board had released a Fugitive Dust Control Self-Inspection Handbook on how to control PM air pollution in urban areas [71]. Some of the recommendations provided are listed herein;

1. Minimize the surface area disturbed, especially for farming areas.

2. Limit dusty work on windy days.

3. Apply dust suppression measures.

4. Clean up dusty spills after work immediately.

5. Grow vegetation ground cover.

6. Use wind erosion controls such as erect wood and rock walls.

7. Apply crust-forming chemicals.

8. Pave haul roads and storage areas.

9. Enclose storage and handling areas.

10. Cover storage piles either with a physical cover or with dust suppressant spray.

11. Water and/or sweep more often.

12. Reduce speed limits on unpaved surfaces.

13. Minimize trips by carpooling and grouping.

14. Prevent transport of dusty materials offsite by rinsing vehicles before they leave the property.

Based on our findings, traffic and construction activities were the two main anthropogenic sources contributing to PM in urban Doha. Hence, the following mitigation policies/ techniques shall be suggested to reduce PM emissions in this area.

i. Encourage more plantation in Qatar: Trees can directly affect particulate matter concentration by (1) removing particles, (2) emitting particles or (3) by the re-suspension of particles on the plant surface [72][73]. In a recent study conducted by Maher et al. [74], silver birch trees were planted in front of several homes in a city block in Lancaster city-United Kingdom. To evaluate the percentage of PM absorbed by the trees, the PM content to which the families were exposed was initially evaluated before plantation. After two weeks of creating a barrier of silver birch trees between the streets with heavy transportation and the homes, it was found that $50 \%$ decrease in PM concentration was achieved. Moreover, the authors used scanning electron microscope (SEM) to study the structure of silver birch tree leaves. They found that tiny hair-like structures on the surface of those leaves were responsible for removing the particulates from the air [74]. Based on the records by The Environment Electronic Encyclopedia, the green area in Qatar is around 4 square meter per capita compared with the average of 25 square meters in 
the world [75][76]. This measure concerns especially the green areas in cities and villages planting of protective greenery, minimization of felling, and compensation of trees with new planting [77][78]. Although these measures do not bring very high environmental effects, they bring other social positive effects and are not very costly. Recently, we have reported on the evaluation of economic and environmental benefits of planting three abundant urban tree species in the State of Qatar [72]. The trees that were investigated (Acacia, Ziziphus and Phoenix dacteylifera) grow naturally in desert areas and require minimum rain and care. The environmental economic value of these species was found to be the highest for Acacia, followed by Ziziphus and then Phoenix decteylifera which is in agreement with their Air Pollution Tolerance Index (APTI). The APTI is a factor used by researchers to assess the tolerance of trees to air pollution, the higher the APTI, the less sensitive the species to pollution. Hence, those studies indicate that, in order to have adequate, green infrastructure-based policies to mitigate air pollution in cities, urban planning that include vegetation should be implemented at lager scales.

ii. Mitigation of PM emissions from construction sites: Construction activities have the potential to generate significant levels of dust, including fine and course particulate matter [79][80]. Construction activities can be generally divided into three main phases: earthwork (phase 1), super construction (phase 2) and finishing (phase 3) [81]. Therefore, general recommendations on the three phases can be summarized in Table 5. At construction sites, dust suppression methods in Qatar ranges from simple pouring or spraying water or the use of dust wetting additives which reduced the surface tension of dust and enhanced its suppression minimizing the amount of water to be used for this purpose [82]. Moreover, The Ministry of Municipality and Environment in Qatar has set a certain protocol to reduce air pollution in construction sites. Some of the main guidelines to ensure safety and environmental protection are related to the elimination of damages resulting from construction, maintenance and demolition works. In addition, the construction site should be fenced. This fence (whether porous or solid) provides an area with reduced wind velocity that minimizes wind erosion and hence, fugitive dust emission from the exposed working area will be reduced.

Several other techniques can be suggested to limit PM emission by construction activities, such as isolating dust-producing activities. For instance, dust-producing activities shall be located, when possible, away from the site boundary, especially from sensitive receptors. Another mitigation guideline is to avoid or minimize construction activities that might generate huge amount of dust on windy days, especially when wind blows in the direction of possible receptors [80].

Table 5. Mitigation of PM emission during different phases of construction activities.

\begin{tabular}{|c|c|c|c|}
\hline & $\begin{array}{c}\text { Phase 1: } \\
\text { Earthworks }\end{array}$ & $\begin{array}{c}\text { Phase 2: } \\
\text { Construction }\end{array}$ & $\begin{array}{l}\text { Phase 3: } \\
\text { Finishing }\end{array}$ \\
\hline \multirow{4}{*}{$\begin{array}{c}\text { Dust } \\
\text { control } \\
\text { methods }\end{array}$} & $\begin{array}{l}\text { Sprinkling } \\
\text { water to the } \\
\text { routes inside of } \\
\text { the jobsite }\end{array}$ & $\begin{array}{l}\text { Sprinkling water } \\
\text { to the } \\
\text { routes inside of } \\
\text { the jobsite }\end{array}$ & $\begin{array}{l}\text { Sprinkling } \\
\text { water to the } \\
\text { routes inside } \\
\text { of the jobsite }\end{array}$ \\
\hline & $\begin{array}{l}\text { Careful traffic } \\
\text { route }\end{array}$ & $\begin{array}{l}\text { Careful traffic } \\
\text { route }\end{array}$ & $\begin{array}{c}\text { Careful } \\
\text { traffic route }\end{array}$ \\
\hline & $\begin{array}{l}\text { All trucks } \\
\text { entering and } \\
\text { leaving site } \\
\text { were covered }\end{array}$ & $\begin{array}{c}\text { All trucks } \\
\text { entering and } \\
\text { leaving site were } \\
\text { covered }\end{array}$ & $\begin{array}{c}\text { All trucks } \\
\text { entering and } \\
\text { leaving site } \\
\text { were covered }\end{array}$ \\
\hline & $\begin{array}{c}\text { Natural, } \\
\text { embedded tyre } \\
\text { cleaning } \\
\text { passage } \\
\text { sections at } \\
\text { gates of the } \\
\text { construction } \\
\text { site }\end{array}$ & $\begin{array}{c}\text { Natural, } \\
\text { embedded tyre } \\
\text { cleaning passage } \\
\text { sections at gates } \\
\text { of the } \\
\text { construction site }\end{array}$ & $\begin{array}{l}\text { Netting } \\
\text { system } \\
\text { around the } \\
\text { tower to } \\
\text { mitigate } \\
\text { dusty façade } \\
\text { mortar } \\
\text { activities }\end{array}$ \\
\hline
\end{tabular}

iii. Reduction of PM emissions from transportation: The reliability of emission profile of a vehicle can be affected by many factors such as fuel types, operating conditions and vehicle types. Although both petrol (gasoline) and diesel fueled cars contribute to air pollution [82], it is the diesel fuel that pollute more nitrogen oxides and PM compared with petrol. That is why many EU countries have adopted legislations to ban the use of diesel cars gradually starting from 2020s. The high rate of particulate matter comes from the diffusion flame that diesel engine uses where droplets of fuels are created that do not have enough time to evaporate while passing through the front flame and hence, pass through it to be emitted to the atmosphere. Alternative fuel has a profound future because it can reduce pollution at the very beginning and costs less compared to other emission reduction methods like engine control technology, exhaust after treatment devices, and lower sulfur content of petrol/diesel. Among all the fuels, natural gas (NG) is considered to be a promising one on the basis of its abundance, low pollution levels and high combustion efficiency [82][83].

On the other hand, several technologies have been developed to reduce PM and gaseous emission from traffic, mainly utilizing nanotechnology and heterogeneous catalysis [51][84][85][86]. The oxidation or lean NOx catalyst in diesel engine vehicles, for instance, does not only reduce gaseous emissions associated with diesel 
burning, but also provides significant PM control. In addition, PM filter systems have been used to achieve greater than $90 \%$ of PM reduction [87]. Another technical example requires engine manufacturers to install electronic idle control that automatically turns the engine off after 5 minutes of continuous idle operation [88].

Moreover, several mitigation policies have been reported and suggested to the decision makers in Qatar, including:

- Restriction on vehicle registration: Due to the fact that there was no limit on the number of cars that someone owns and the increasing number of driving licenses issued to citizens and expatriates who live and work in Qatar. The government issued a decision in 2013 to ban some categories of expatriate workers from obtaining a driving license. Nevertheless, the latest data show that there was $17 \%$ increase in the number of licenses issued for citizens and $2.9 \%$ for expatriates by 2015 [82]. Therefore, more stringent measures should be taken to make an effective impact of such a law to reduce vehicle pollutions on roads.

- Road Transportation Management: Qatar has developed many infrastructure projects around the country. Some has caused restrictions in traffic that contributed to pollution from vehicles idling when they have to stop for long times. Nevertheless, these projects once executed, there will be an increase of fluidity and traffic congestion reduction which will have an impact on emission control. These projects include bypasses roads, parking places connected to public transport, and public transportation development, including integrated transportation systems. Protecting against secondary dust emissions (street cleaning and sprinkling) is part of this sort of measure [89]. Moreover, down at the street level, Mowasalat (the Arabic Translation for the word "transportation") as the $100 \%$ government owned Transport Company to provide public transportation, is on the frontline to improve Qatar's transport system since it was established in 2002. Among its fleet of taxis and limos, Mowasalat has new network of public bus routes to meet the demands of an estimated of 50,000 daily commuters. Long term development plans at Mowasalat include many overall network improvements. Their main aim is to provide a sustainable and efficient transport system and obtain better mobility to all citizens, residents and visitors to Qatar [82]. In addition, a prospective underground metro train system (Qatar Rail) is also expected to significantly reduce road transportation needs and activities. Choice of Qatar Rail metro stations and local access means to these stations should be conducted to minimize road transportation needs considering the demographic make-up, cultural considerations and climate conditions such as designing underground access alleys or streets to these stations from neighboring localities.

\section{Conclusion, Limitations and Future Work}

This paper has presented a preliminary study on the characterization of nine dust samples that were collected around urban Doha in Winter 2016/2017. The three locations represented residential, construction and transportation sites. The results show that the particles were mostly spherical with an average diameter size of $7.38 \mu \mathrm{m}$ while larger particles up to $100 \mu \mathrm{m}$ were also observed due to agglomeration. The average shape factor and aspect ratio of the particles were found to be 2.54 and 1.77 , respectively. These values affect the contact area between particles and substrates on which they might accumulate, hence affecting the adhesion force strength. The average annual dust fallout rate was found to be around 3.7 Ton $/ \mathrm{km}^{2}$. The $\mathrm{pH}$ of the mud liquid of the dust samples was found to be in the range of 7.51-7.88 indicating that the solution is slightly basic due to the presence of alkaline and alkaline earth metals in dust when dissolved in water. The elemental composition revealed that calcium and silicon were the most abundant elements indicating that dust in this area is mostly calcite and silicate in agreement with other studies reported for dust composition in the region. The enrichment factor showed that $\mathrm{Cl}$ and $\mathrm{S}$ had extreme high enrichment due to sea salt and traffic emission sources, respectively, while $\mathrm{Ca}$ had significant enrichment due to the domination of calcite minerals. To investigate the possible sources of the dust samples, the elemental analysis was conducted and revealed that almost $60 \%$ of the composition comes from natural sources such as soil/crustal matter, sea salt and desert dust. On the other hand, the anthropogenic sources accounted for about $40 \%$ and they come mainly from transportation and construction activities.

To mitigate the impact of PM in urban Doha, several mitigation strategies and techniques have been proposed against the main anthropogenic polluting sources especially during construction and with relation to traffic pollution. Moreover, green plantation was suggested as one of the most effective methods to abate urban PM pollution. Nevertheless, several limitations can be mentioned in this type of research which is the need to collect and analyze more samples all around the year and from different locations including rural areas which also requires human capital and time for sample collection and analysis. Moreover, filter analysis from fixed or mobile air quality stations would provide more accurate results especially for particle source speciation. These activities have been conducted recently at larger scale in the country through 
our research at Qatar Environment and Energy Research Institute/ Hamad Bin Khalifa University where publication for the first full year data on PM characterization and sources of about 50 samples collected monthly is under preparation.

\section{Nomenclature}

$\begin{array}{cc}\text { A } & \text { Cross sectional area of the particle } \\ \text { A }_{\text {shape }} & \text { Shape factor } \\ \text { COP } & \text { Conference of the Parties, relates to The United Nations } \\ \text { Ct } & \text { Climate Change Conferences } \\ \text { EF } & \text { Aspect ratio } \\ \text { E }_{\text {Factor }} & \text { Enrichment factor } \\ \text { EDS } & \text { Emission factor } \\ \text { EU } & \text { Electron Dispersive x-ray Spectroscopy } \\ \text { GCC } & \text { European Union } \\ \text { GDP } & \text { Gulf Cooperation Council } \\ \text { KSA } & \text { Gross domestic product } \\ \text { kWh } & \text { Kingdom of Saudi Arabia } \\ \text { L } & \text { kilowatt hour } \\ \text { NG } & \text { The longest projection length of the particle } \\ \text { pH } & \text { Natural gas } \\ \text { PIK } & \text { Potsdam Institute for Climate Impact Research } \\ \text { PM } & \text { Particulate Matter } \\ \text { UAE } & \text { United Arab Emirates } \\ & \end{array}$

\section{Acknowledgements}

We acknowledge financial support from Qatar Environment and Energy Research Institute (QEERI), at Hamad Bin Khalifa University-Qatar Foundation (Doha, Qatar). Authors would like to thank Eng. Wafa Suwaileh for the SEM images, alkalinity and EDS data. Also, we would like to thank Mr. Benjamin Figgis at QEERI/HBKU Solar Test Facility for providing information related to the wind direction at the time of the study.

\section{Author Contributions}

H. A., M. K. and R. I. contributed for the analysis of data obtained and writing the article.

\section{Additional Information}

Competing financial interests: The authors declare no competing financial interests.

\section{REFERENCES}

[1] W. Zhao, J. Cheng, D. Li, Y. Duan, H. Wei, R. Ji, et al., Urban ambient qir quality investigation and health risk assessment during haze and non-haze periods in Shanghai, China, Atmos. Pollut. Res. 4 (2013) 275-281.

[2] C. Perrino, S. Tiwari, M. Catrambone, S.D. Torre, E. Rantica, S. Canepari, Chemical characterization of atmospheric PM in Delhi, India, during different periods of the year including Diwali festival, Atmos. Pollut. Res. 2 (2011) 418-427.

[3] A. Panas, A. Comouth, H. Saathoff, T. Leisner, M. Al-Rawi, M. Simon, et al., The Elemental Composition of Atmospheric Particles at Beijing during Asian Dust Events in Spring 2004, Beilstein J. Nanotechnol. 5 (2014) 15901602.

[4] L. Liu, B. Urch, R. Poon, M. Szyszkowicz, M. Speck, D.R. Gold, et al., Effects of ambient coarse, fine, and ultrafine particles and their biological constituents on systemic biomarkers: A controlled human exposure study, Environ. Health Perspect. 123 (2015) 534-540.

[5] M. Zhang, Y. Song, X. Cai, J. Zhou, Economic sssessment of the health effects related to particulate matters pollution in 111 Chinese cities by using economic burden of disease analysis, J. Environ. Manage. 88 (2008) 947-954.

[6] P. Davy, G. Gunchin, A. Markwitz, W. Trompetter, B. Barry, D. Shagjjamba, et al., Air particulate matter pollution; determination of composition, source contribution and source locations in Ulaanbaatar, Mongolia, Atmos. Pollut. Res. 2 (2011) 126-137.

[7] M. Kampa, E. Castanas, Human health of air pollution, Environ. Pollut. 151 (2008) 362-367.

[8] B. Begum, P. Hopke, A. Markwitz, Air pollution by fine particulate matter in Bangladesh, Atmos. Pollut. Res. 4 (2013) 75-86.

[9] E. Sarti, L. Pasti, M. Rossi, M. Ascanelli, A. Pagnoni, M. Trombini, et al., The composition of PM1 and PM2.5 samples, metals and their water soluble fractions in the Bologna area (Italy), Atmos. Pollut. Res. 6 (2015) 708-718.

[10] R. Zhang, J. Cao, Y. Tang, R. Arimoto, Z. Shen, F. Wu, et al., Elemental profiles and signatures of fugitive dusts from Chinese deserts, Sci. Total Environ. 472 (2014) 1121-1129.

[11] M. Khodeir, M. Shamy, Costa, L. Chen, P. Maciejczyk, Source apportionment and elemntal composition of PM2.5 and PM10 in Jeddah city, Saudi Arabia, Atmos. Pollut. Res. 3 (2012) 331-340.

[12] N.M. Hamdan, H. Alawadhi, N. Jisrawi, Elemental and Chemical Analysis of PM10 and PM2.5 Indoor and Outdoor Pollutants in the UAE, Int. J. Environ. Sci. Dev. 6 (2015) 566-570.

[13] S. Fuzzi, U. Baltensperger, K. Carslaw, S. Decesari, H.D. Van Der Gon, M.C. Facchini, et al., Particulate matter, air quality and climate: lessons learned and, Atmos. Chem. Phys. (2015) 8217-8299.

[14] A. Modaihsh, A. Ghoneim, F. Al-Barakah, M. Mahjoub, M. Nadeem, Characterization of deposited dust fallout in Riyadh city, Saudi Arabia, Polish J. Environ. Stud. 26 (2017) 
$1599-1605$.

[15] W. Javed, Y. Wubulikasimu, B. Figgis, B. Guo, Characterization of dust accumulated on photovoltaic panels in Doha, Qatar, Sol. Energy. 142 (2017) 123-135.

[16] B. Aissa, R.J. Isaifan, A. Abdulla, V. Madhavan, Structural and physical properties of the desert-dust particles and their influence on the PV panels performance in Qatar, Sci. Rep. 6 (2016) 31467.

[17] J. Al-Awadhi, A. AlShuaibi, Dust fallout in Kuwait city: Deposition and characterization, Sci. Total Environ. 461462 (2013) 139-148.

[18] A. Al-Dousari, J. Al-Awadhi, Dust fallout in northern Kuwait, major sources and characterization, Kuwait J. Sci. 39 (2012) 171-187.

[19] R. Gorham, Air Pollution from Ground Transportation, 2002.

[20] S. Jalihal, T. Reddy, Compressed Natural Gas: An alternative fuel for public transport, J. Sci. Ind. Res. (India). 65 (2006) 426-431.

[21] G. Martin, Researches on the theory of fine grinding, Br. Ceram. Trans. 23 (1923) 61-109.

[22] A. Heywood, A comparison of methods of measuring microscopic particles, Trans. Inst. Min. Metall. 55 (1946) 391-404.

[23] R.J. Isaifan, S. Ntais, M. Couillard, E.A. Baranova, Size-dependent activity of $\mathrm{Pt} / \mathrm{yttria}$-stabilized zirconia catalyst for wireless electrooxidation of ethylene and carbon monoxide in oxygen free environment, J. Catal. 324 (2015) 32-40.

[24] P. Maas, A literature (review) study on the health and environmental effects of Particulate Matter in the Netherlands, Amsterdam, 2007.

[25] J. Goldstien, D. Newbury, P. Joy, A. Lyman, C. Lifshin, Scanning Electron Microscopy and X-Ray Microanalysis: A Text for Biologists, Material Scientists and Geologists, Plenum Press, New York, USA, 2012.

[26] A.S. Likuku, K.B. Mmolawa, G.K. Gaboutloeloe, Assessment of Heavy Metal Enrichment and Degree of Contamination Around the Copper-Nickel Mine in the Selebi Phikwe Region, Eastern Botswana, Environ. Ecol. Res. 1 (2013) 32-40.

[27] M. Barbieri, Geology \& Geophysics The Importance of Enrichment Factor ( EF ) and Geoaccumulation Index ( Igeo ) to Evaluate the Soil Contamination, Geol. Geophys. 5 (2016) 1-4.

[28] P. Khillare, S. Sarkar, Airborne inhalable metals in residential areas of Delhi, India: distribution, source apportionment and health risks, Atmos. Pollut. Res. 3 (2012) $46-54$.

[29] Y. Sun, G. Zhuang, Y. Wang, L. Han, J. Guo, M. Dan, et al., The Air-Borne Particulate Pollution in Beijing-Concentration, Composition, Distribution and Sources., Atmos. Environ. 38 (2004) 5991-6004.

[30] A. Rushdi, K. Al-Mutlaq, M. Al-Otaibi, A. El- Mubarak, B. Simoneit, Air quality and elemental enrichment factors of aerosol particulate matter in Riyadh City , Saudi Arabia, Arab. J. Geosci. 6 (2013) 585-599.

[31] M. Al-Dabbas, M. Abbas, R. Al-Khafaji, Dust storms loads analysis-Iraq, Arab. J. Geosci. 5 (2012) 121-131.

[32] S. O'Hara, M. Clarke, M. Elatrash, Field measurements of desert dust deposition in Libya, Atmos. Environ. 40 (2006) 3881-3897.

[33] M. Reheis, A 16-year record of eolian dust in Southern Nevada and California, USA: controls on dust generation and accumulation, J. Arid Environ. 67 (2006) 487-520.

[34] T. Hu, J. Cao, K. Ho, Z. An, S. Lee, C. Judith, et al., Winter and Summer Characteristics of Airborne Particles Inside Emperor Qin's Terra-Cotta Museum, China: A Study by Scanning Electron Microscopy - Energy Dispersive X-Ray Spectrometry Winter and Summer Characteristics of Airborne Particles Inside Emper, J. AIr Waste Manag. Assoc. 61 (2011) 914-922.

[35] R. Aryal, R. Naidu, P. Loganathan, Seasonal influence on urban dust PAH profile and toxicity in Sydney, Australia, Water Sci. Technol. 63 (2011) 2238-2243.

[36] B.S. Yilbas, H. Ali, M.M. Khaled, N. Al-Aqeeli, N. Abu-Dheir, K.K. Varanasi, Influence of dust and mud on the optical, chemical, and mechanical properties of a pv protective glass, Sci. Rep. 5 (2015) 15833.

[37] M. Ranade, Adhesion and Removal of Fine Particles on Surfaces, Aerosol Sci. Technol. 7 (1987) 161-176.

[38] R. Jones, H.M. Pollock, J.A.S. Cleaver, C.S. Hodges, Adhesion forces between glass and silicon surfaces in air studied by AFM : Effects of relative humidity, particle size, roughness and surface treatment., Langmuir. 18 (2002) 8045-8055.

[39] R.J. Isaifan, A. Samara, W. Suwaileh, D. Johnson, W. Yiming, A.A. Abdallah, et al., Improved Self-cleaning Properties of an Efficient and Easy to Scale up TiO2 Thin Films Prepared by Adsorptive Self-Assembly, Sci. Rep. 7 (2017) 9466.

[40] G. Hassan, B. Yilbas, S. Said, N. Al-Aqeeli, A. Matin, Chemo-Mechanical Characteristics of Mud Formed from Environmental Dust Particles in Humid Ambient Air, Sci. Rep. 6 (2016) 30253.

[41] E. Coz, F.J. Gómez-Moreno, G.S. Casuccio, B. Artíñano, Variations on morphology and elemental composition of mineral dust particles from local, regional, and long-range transport meteorological scenarios, J. Geophys. Res. 115 (2010) 1-12.

[42] Z. Guo, Z. Li, J. Farquhar, A. Kaufman, N. Wu, C. Li, et al., Identification of sources and formation processes of atmospheric sulfate by sulfur isotope and scanning electron microscope measurements, J. Geophys. Res. 115 (2010) 113.

[43] M. Cecile-Chalbot, M. Lianou, I. Christina Vei, A Kotronarou, I. Kavouras, Spatial attribution of sulfate and dust aerosol sources in an area using receptor modeling coupled with Lagrangian trajectories, Atmos. Pollut. Res. 4 (2013) 346-353.

[44] F.G. Ofosu, P.K. Hopke, I.J.K. Aboh, S.A. Bamford, Atmospheric Pollution Research Characterization of fine 
particulate sources at Ashaiman in Greater, Atmos. Pollut. Res. 3 (2012) 301-310.

[45] E.A. Reid, J.S. Reid, M. Meier, M. Dunlap, S. Cliff, A. Broumas, et al., Characterization of African dust transported to Puerto Rico by individual particle and size segregated bulk analysis, J. Geophys. Res. 108 (2003) 8591-8598.

[46] P. Pant, R. Harrison, Critical review of receptor modelling for particulate matter: A case study of India, Atmos. Environ. 49 (2012) 1-12.

[47] P. Formenti, S. Caquineau, K. Desboeufs, A. Klaver, S. Chevaillier, E. Journet, et al., Mapping the physico-chemical properties of mineral dust in western Africa: mineralogical composition, Atmos. Chem. Phys. (2014) 10663-10686.

[48] W. Abdulqaderismaeel, A. Kusag, Enrichment Factor and Geo-accumulation Index for Heavy Metals at Industrial Zone in Iraq, IOSR J. Appl. Geol. Geophys. 3 (2015) 2632.

[49] D. Saraga, T. Maggos, E. Sadoun, F. Fthenou, H. Hassan, V. Tsiouri, et al., Chemical characterization of indoor and outdoor particulate matter in Doha, Qatar, Aerosol Air Qual. Res. 5 (2017) 1-13.

[50] S. Arslan, A. Aybek, Particulate Matter Exposure in Agriculture, IntechOpen, 2012.

[51] N. Hooftman, L. Oliveira, M. Messagie, T. Coosemans, J. Van Mierlo, Environmental analysis of petrol, diesel and electric passenger cars in a Belgian urban setting, Energies. 9 (2016) 1-24.

[52] S. Police, S.K. Sahu, G.G. Pandit, Chemical characterization of atmospheric particulate matter and their source apportionment at an emerging industrial coastal city , Atmos. Pollut. Res. 7 (2016) 725-733.

[53] M. Viana, T. Kuhlbusch, X. Querol, A. Alasruey, R. Harrison, P. Hopke, et al., Source apportionment of particulate matter in Europe: A review of methods and results, J. Aerosol Sci. 39 (2008) 827-849.

[54] E. Al Katheeri, F. Jallad, M. Al Omar, Aassesmnet of gaseous and particlulate pollutants in the ambient air of $\mathrm{Al}$ Mirfa City in the United Arab Emirates, J. Environ. Prot. (Irvine,. Calif). 3 (2012) 640-647.

[55] P. Davy, T. Ancelet, W. Trompetter, A. Markwitz, D. Weatherburn, Composition and source contributions of air particulate matter pollution in a New Zealand suburban town, Atmos. Pollut. Res. 3 (2012) 143-147.

[56] M. Santoso, D. Lestiani, R. Mukhtar, E. Hamonangan, H. Syafrul, A. Markwitz, et al., Preliminary study of the source of ambient air pollution in Serpong, Indonesia, Atmos. Pollut. Res. 2 (2011) 190-196.

[57] S.M. Almeida, C.A. Pio, M.C. Freitas, M.A. Reis, M.A. Trancoso, Approaching PM2.5 and PM2.5 - 10 source apportionment by mass balance analysis, principal component analysis and particle size distribution, Sci. Total Environ. 368 (2006) 663-674.

[58] E. Andrews, P. Saxena, S. Musarra, M. Hildemann, P. Koutrakis, P. McMurry, Concentration and composition of atmospheric aerosols from the 1995 SEAVS experiment and a review of the closure between chemical and gravimetric measurements, J. Air Waste Manag. Assoc. 50 (2000) 648-664.

[59] Y.-J. Han, S.-R. Kim, J.-H. Jung, Long-term measurements of atmospheric PM2.5 and its chemical composition in rural Korea, J. Atmos. Chem. 68 (2011) 281-298.

[60] E. Poulakis, C. Theodosi, M. Bressi, J. Sciare, V. Ghersi, N. Mihalopoulos, Airborne mineral components and trace metals in Paris region: spatial and temporal variability, Environ. Sci. Pollut. Res. 22 (2015) 14663-14672.

[61] T. Grigoratos, G. Martini, Non-exhaust traffic related emissions. Brake and tyre wear PM, Ispra, Italy, 2014.

[62] Y. Tobo, D. Zhang, N. Nakata, M. Yamada, H. Ogata, K. Hara, et al., Hygroscopic mineral dust particles as influenced by chlorine chemistry in the marine atmosphere, Geophys. Res. Lett. 36 (2009) 1-5.

[63] L.R. Martin, H.S. Judeikis, M. Wun, Heterogeneous reactions of $\mathrm{Cl}$ and $\mathrm{ClO}$ in the stratosphere, J. Geophys. Res. 85 (1980) 5511-5518.

[64] Sivasakthivel.T, K. Reddy, Ozone Layer Depletion and Its Effects: A Review, Int. J. Environ. Sci. Dev. 2 (2011) 3037.

[65] M. Tanomaru-Filho, A. Garcia, R. Bosso-Martelo, F. Berbert, J. Reis, J. Guerreiro-Tanomaru, Influence of addition of calcium oxide on physicochemical properties of Portland cement with zirconium or niobium oxide, J. Conserv. Dent. 18 (2015) 105-108.

[66] L. Frank, K. Sisomphon, A new chemical method for analyzing free calcium hydroxide content in cementing material, Cem. Concr. Res. 34 (2004) 1161-1165.

[67] M. Faridul Isalam, S. Majumder, A. Al Mamun, M. Khan, M. Arifur Rahman, A. Salam, Trace Metals Concentrations at the Atmosphere Particulate Matters in the Southeast Asian Mega City ( Dhaka, Bangladesh ), Open J. Air Pollut. 4 (2015) 86-98.

[68] M. Dall'Osto, D.C.S. Beddows, R.M. Harrison, B. Onat, Fine Iron Aerosols Are Internally Mixed with Nitrate in the Urban, Eur. Atmos. Environ. Sci. Technol. 50 (2016) 4212 4220 .

[69] K. Cheung, L. Ntziachristos, T. Tzamkiozis, J. Schauer, Z. Samaras, K. Moore, et al., Emissions of particulate trace elements, metals and organic species from gasoline, diesel and biodisealpassenger vehicles and their relation to oxidative potential, Aerosol Sci. Technol. 44 (2010) 500 513.

[70] S. Schaltegger, T. Synnestvedt, The link between green and economic success: environmental management as the crucial trigger between environmental and economic performance, J. Environ. Manage. 65 (2002) 339-346.

[71] California Air Resources Board, Fugitive Dust Control Self-Inspection Handbook, Sacramento, California, 2010.

[72] R.J. Isaifan, H. Al-Thani, M. Ayoub, B. Aissa, M. Koc, The economic value of common urban trees in the State of Qatarfrom an air quality control perspective, J. Environ. Sci. Pollut. Res. 4 (2018) 285-288.

[73] W. Selmi, C. Weber, E. Rivière, N. Blond, L. Mehdi, D. 
Nowak, Air pollution removal by trees in public green spaces in Strasbourg city, France, Urban For. Urban Green. 17 (2016) 192-201.

[74] B. Maher, I. Ahmed, B. Davison, V. Karloukovski, R. Clarke, Impact of roadside tree lines on indoor concentrations of traffic derived particulate matter, Environ. Sci. Technol. 47 (2013) 13737-13744.

[75] C. Lanouar, A.Y. Al-malk, Air Pollution in Qatar: Causes and Challenges Air Pollution in Qatar: Causes and Challenges, WP/CBE. 1 (2016) 0-7.

[76] D. Pimente, T.W. Patzek, Ethanol Production Using Corn, Switchgrass, and Wood; Biodiesel Production Using Soybean and Sunflower., Nat. Resour. Res. 14 (2005) 6576.

[77] M. Ghose, S. Majee, Air pollution caused by opencast mining and its abatement measures in India, J. Environ. Manage. 63 (2001) 193-202.

[78] N. Powe, K. Willis, Mortality and morbidity benefits of air pollution ( $\mathrm{SO} 2$ and PM10) absorption attributable to woodland in Britain, J. Environ. Manage. 70 (2004) 119128.

[79] I. Araújo, D. Costa, R. Moraes, Identification and Characterization of Particulate Matter Concentrations at Construction Jobsites, Sustainability. 6 (2014) 7666-7688.

[80] Y. Al Horr, GSAS: Construction Management: Guidelines \& Assessment 2017, 2017.

[81] F. Resende, F.F. Cardoso, D.B. Costa, A. Melo, I.P.S. Araújo, R.J.B. Moraes, et al., Methodology for Measuring the Concentration of Particulate Material in Construction Sites, in: Proc. SIBRAGEC 2013-8th Brazilian Symp. Constr. Manag. Econ. Innov. Sustain. Brazilian Assoc.
Built Environ. Technol. (ANTAC), Salvador, 2013: pp. 1820 .

[82] The Peninsula Newspaper, Call to control number of cars on the roads, Qatar Living. (2015). www.qatarliving.com/foru $\mathrm{m} /$ news/posts/call-control-number-cars-roads.

[83] X. Huang, Y.Z. Xing, K. Dua, Emission factors of air pollutants fromCNG-gasoline bi-fuel vehicles: Part II. CO, HC and NOx., Sci. Total Environ. 565 (2016) 698-705.

[84] R.J. Isaifan, E.A. Baranova, Catalytic electrooxidation of volatile organic compounds by oxygen-ion conducting ceramics in oxygen-free gas environment, Electrochem. Commun. 27 (2013).

[85] R.J. Isaifan, E.A. Baranova, Effect of ionically conductive supports on the catalytic activity of platinum and ruthenium nanoparticles for ethylene complete oxidation, Catal. Today. 241 (2015)

[86] R.J. Isaifan, H.A.E. Dole, E. Obeid, L. Lizarraga, E.A. Baranova, P. Vernoux, Catalytic CO oxidation over Pt nanoparticles prepared from the polyol reduction method supported on Yttria-Stabilized Zirconia, in: ECS Trans., 2011.

[87] J. Sharaf, Exhaust emissions and its control technology for internal combustion engine, Int. J. Eng. Res. Appl. 3 (2013) 947-960.

[88] California Environmental Protection Agency, Proposed list of measures to reduce particulate matter-PM10 and PM2.5, 2004.

[89] P. Šauer, J. Kreuz, A. Lisa, Assessing Efforts to Mitigate Particulate Matter Air Pollution in the Moravian-Silesian Region, Polish J. Environ. Stud. 23 (2014) 2233-2242. 